\title{
Diálogos catequéticos coloniais: cena textual versus performance
}

Marcello Moreira*

Universidade Estadual do Sudoeste da Bahia, Vitória da Conquista - BA, Brasil

\section{RESUMO}

Objetiva-se demonstrar a aplicação de preceitos retóricos quando da composição de diálogos catequéticos no Estado do Brasil, correlacionando-se a enunciação jesuítica sobre a participaçâo de índios na fatura das traduçôes dos catecismos para as línguas peregrinas do Novo Mundo - o que indiciaria a presença de uma fala índia ainda rumorejante nesses diálogos —, e o estilo pedestre próprio do gênero "diálogo", com vistas a patentear como essa correlação produz o efeito da "naturalidade da fala selvagem" e, também, o da falta de aplicação de artifício compositivo por parte dos padres da Companhia de Jesus. Discute-se, outrossim, como a "cena" em que dialogam catequista e catecúmeno fixa um modelo para posterior replicação em situaçôes de prática catequética, "cena" essa que, no entanto, era infletida de vários modos pelo hiato entre modelo textual e performance. Por fim, discute-se como a escritura de diálogos, ao se apropriar da fala índia, só o faz para nela inscrever as matérias sacras, as verdades da fé católica, que caberá ao índio, por repetição e interiorização do que repetidamente enuncia, inscrever em si mesmo como duplo do catecúmeno que, nos diálogos, é um seu reflexo perfeito, reflexo que, no entanto, se embacia quando da prática catequética pela impossibilidade de o índio "atuar" como o modelo mimético que o representa à sua revelia.

Palavras-chave: retórica epidítica; catequização; Estado do Brasil; diálogos; Aristóteles; Poética.

\section{ABSTRACT}

This paper's goal is to demonstrate how rhetorical precepts were applied to catechetical dialogues composed in Portuguese South America. It correlates Jesuit statements about the participation of Native Brazilians in the production of translations into their languages (native speech still rustles in the dialogues) with the pedestrian style of the "dialogue" genre itself. The paper endeavors to show how such correlation produced the effect of "naturalness

DOI - http://dx.doi.org/10.1590/2237-101X017033002

Artigo recebido em 15 de fevereiro de 2016 e aprovado para publicaçáo em 10 de outubro de 2016.

* Professor titular de Letras Luso-Brasileiras (séculos XVI, XVII e XVIII) e de Historiografia e História Literária da Universidade Estadual do Sudoeste da Bahia - DELL, Estrada do Bem Querer, km 4, Vitória da Conquista, BA, CEP: 45083-900. E-mail: moreira.marcello@gmail.com. 
of savage speech," and also demonstrates the lack of application of artificial composition by the priests of the Society of Jesus. Lastly, we discuss how dialogue writing appropriates native speech only as a means to include in it the sacred truths of the Catholic faith, leaving to Native Brazilians the task of ascribing such truths to themselves through repetition and internalization, as a stunt double of the catechumen in the dialogues, as its perfect reflection. In the catechetical practice, though, such reflection is blurred, as it is impossible for the native to "act" as the mimetic model that represents him in absentia.

Keywords: epideictic rhetoric; Portuguese America; dialogues; Aristotle; Poetics.

(I)

Como se sabe, a primeira gramática geral de língua indígena do Estado do Brasil é a de José de Anchieta (1595), a que se seguiram outras compostas nos séculos XVII e XVIII, muitas delas pela ação missionária de membros da Companhia de Jesus. Uma dessas línguas a ganhar, não gramática, conquanto essa esteja implícita em qualquer texto escrito em uma dada língua, mas um catecismo, foi a chamada língua da nação kiriri. "Kiriri", sabe-se, significa em tupi "taciturno" ou "calado", predicado por meio do qual os índios da costa denominaram alguns grupos indígenas do sertâo. Em seu Catecismo composto em língua da nação “kiriri”, pertencente ao grupo macro-jê, o jesuíta Luís Vincêncio Mamiani (1652-1730) justificou a composição de um catecismo da doutrina cristã nessa língua pela necessidade que sentiram os padres da Companhia de penetrar nos sertóes "interiores" para "reduzir ao rebanho de Christo também os Indios bravos \& Tapuyas", ${ }^{1}$ sendo os índios da nação kiriri aqueles "que tiveram essa sorte", a de ser os primeiros beneficiados da ação missionária de catequização jesuítica sertôes adentro.

Valendo-se de um lugar-comum de gramáticas de línguas peregrinas do Novo Mundo, compostas pela ação missionária europeia, Mamiani assevera nada ser tão útil "à persuasão dos índios à fé de Cristo" do que a notícia de suas línguas. ${ }^{2} \mathrm{O}$ extrato permite compreender que a "notícia" de qualquer língua peregrina, ou seja, seu conhecimento, é condição prévia a que se dê um discurso persuasivo dirigido aos falantes dessas mesmas línguas, o que implica ser a gramática uma propedêutica para a oratória e outros escritos em que lugares-comuns epidíticos, deliberativos e judiciais são atualizados. Contrariamente ao dom das línguas de que os apóstolos foram os beneficiários ("Sendo pois que o meyo principal para persuadir aos

\footnotetext{
${ }^{1}$ MAMIANI, Luís Vincêncio. Catecismo da doutrina cristã na língua brasílica da Nação Kiriri. Lisboa: Miguel Deslandes, 1698, Ao Leytor, p. 1.

${ }^{2}$ Ibidem, p. 1.
} 
Gentios a Fè de Christo he a noticia das suas línguas tam necessaria, que o mesmo Christo a quis comunicar com hum prodigio aos primeiros missionarios do mundo, que forão os Apostolos"), lugar esse comuníssimo em gramáticas, cartilhas, catecismos, dentre outros, dirigidos ao uso de catequistas, os novos apóstolos de Cristo nos tempos modernos têm de por esforço não mínimo aprender as línguas dos povos a serem convertidos à fé cristã, cujas dificuldades são sempre mencionadas para dar a entender aos padres da Europa, interlocutores dos padres missionários, o sacrifício ingente que significa viver entre os índios bravios para, pelo convívio, chegar a compreender algo de sua língua: exaltação da humildade e obediência ao que ordena, como o diz Mamiani, o próprio "Instituto" da Companhia de Jesus:

Há mais de vinte \& cinco anos, que os Religiosos da Companhia desta Provincia do Brasil desejosos de dilatar, conforme o proprio Instituto, as conquistas da Fè na Gentilidade Brasilica, \& não satisfeitos do que tinhão obrado com os Indios maritimos da lingua geral, penetrarão os Certôes interiores deste Brasil, para reduzir ao rebanho de Christo tambem os indios bravos, \& Tapuyas. ${ }^{3}$

O aprendizado das línguas peregrinas, desse modo, instrumento de catequização e conversão de povos "bárbaros" espalhados pelo mundo, constitui-se como um procedimento previsto pela ação missionária da Companhia de Jesus, ação essa que busca na emulação do apostalado antigo uma justificação para si própria, ainda mais quando o que era dom torna-se sacrifício pelo esforço dispendido para o domínio das línguas bárbaras dificílimas de aprender. Mamiani não se poupa de referir a dificuldade de aprendizado da língua da nação kiriri, o que amplifica o louvor de sua empreitada, já que, sendo ele "mínimo", como diz de si próprio, consegue, no entanto, atender a uma ordem dos seus superiores para que faça um catecismo da doutrina cristã nessa língua, a que chama "obrinha", contraponto do "dificultoso assunto", que é o aprendizado do kiriri: "Mas como atè gora naó houve quem quizesse, ou pudesse tomar esta obrinha a seu cargo, Eu, ainda que o minimo de todos, por mandado dos meus Superiores aceitei este dificultoso assumpto para utilidade dos novos Missionarios, \& para bem de tantas almas".

O que justifica ter Mamiani aceitado preparar a obrinha é não apenas sua obediência aos superiores, mas, sobretudo, o fato de ser um conhecido linguista, aprovado por outros linguistas mais velhos, que também conhecem o kiriri. Esse domínio do kiriri deve-se a uma constante exposição aos falantes, e ao reparo no modo de falar de índios de vários aldeamentos, reparo esse acompanhado de constante notação do que ouvia e das respostas ao que perguntava quando, ao ouvir, desejava saber exatamente o que diziam os índios e do que significavam ao comunicar-se uns com os outros ou com ele.

\footnotetext{
${ }^{3}$ Idem.

${ }^{4}$ Ibidem, p. 2. 
Quando da composição do Catecismo da doutrina cristã na língua brasilica da nação kiriri, houve a conferência do catecismo pelos línguas mais antigos da Companhia, conhecedores do kiriri, conferência essa que se minudenciou em uma análise da tradução para o kiriri de natureza linear, quando entáo se escrutinou o sentido dos textos traduzidos palavra por palavra, quando esse procedimento tinha cabimento, ou por meio das circunlocuçóes, quando a tradução por equivalências vocabulares não era permitida. Essa análise da tradução, sentença por sentença, contou com o necessário auxílio de índios, capazes de dizer, ao ouvir ler o texto em português, o que seriam os equivalentes semânticos em sua própria língua, de que deriva serem os índios em parte tradutores dos vários textos que compóem o Catecismo de Mamiani. Pode-se, portanto, supor que os índios são línguas eles próprios, ao declararem ou não a equivalência entre o texto português e o seu correspondente kiriri. Desse modo, não há apenas nos escritos de Mamiani uma língua índia, mas há também uma voz índia, mesmo que consideremos uma certa modelização dessa língua pelo seu uso em poemas e diálogos. Nos diálogos de Mamiani, portanto, produz-se a crença, quando se assevera que os índios participaram ativamente das traduçôes dos textos portugueses para o kiriri, de que o diálogo catequético é fruto de uma relação verdadeiramente dialógica entre catequistas e catecúmenos, estando esses últimos tâo de acordo com aqueles que puderam produzir fruto comum, o que faz supor que o diálogo, esse fruto comum, atualizava-se sempre como perfeita comunhão, replicando-se como mútua concordância.

João Adolfo Hansen, em estudo seminal sobre os poemas em língua tupi compostos por José de Anchieta, declara que vários procedimentos de domesticação da língua índia se fazem neles presentes. Em primeiro lugar, há um dispositivo descontextualizador de significaçôes, "aplicado no processo de conquista espiritual efetivada pelos padres", 5 que subordina e integra o índio em novas relaçóes de poder. Desse modo, quando se dá, por exemplo, a recitaçáo de um poema em língua tupi por um índio,

Na recitação do monólogo, o poema produz o destinatário como o "eu" de uma pessoa católica dotada de interioridade anímica. Assim, quando o destinatário/leitor ocupa o lugar do corpo imaginário do personagem "índio", que aparece todo em tupi mas respirando como um católico medieval, a mescla teológico-linguística captura o corpo do destinatário como um veículo para a fala da alma católica. ${ }^{6}$

Esse processo de captura do corpo do destinatário índio "como um veículo para a fala da alma católica” parece ter sido um procedimento recorrente em escritos jesuíticos, com vário

\footnotetext{
${ }^{5}$ HANSEN, João Adolfo. A escrita da conversão. In: COSTIGAN, Lúcia Helena (Org.). Diálogos da conversão. São Paulo: Edusp, 2005, p. 15-43 [p. 35].

${ }^{6}$ Ibidem, p. 35.
} 
grau de sucesso e com importantes inflexóes inclusive na imitação de um pneuma cristão que ritmaria a fala índia.

A atividade propriamente dialogal dos diálogos catequéticos compostos por Mamiani, e que ele não apenas nos deixa entrever, mas, de certa maneira, faz questão de que vejamos, é, sem sombra de dúvida, aquela que supostamente antecede a composição dos "textos" dos diálogos catequéticos, ou seja, é a interlocução que se dá entre Mamiani e os índios línguas com quem ele conversa sobre as equivalências linguísticas entre a sua língua e aquela dos índios, diálogo esse de natureza "tateante", em que cada frase necessita de avaliação por parte de intérpretes europeus e índios, ${ }^{7}$ pois, como o declara o próprio Mamiani, por mais bons línguas que sejam os padres da Companhia, o kiriri é tão "embaraçado" - e a palavra não foi escolhida aleatoriamente — , que somente um falante nativo é capaz de realmente desembaraçá-lo. ${ }^{8}$ Ao traduzir do português para o kiriri, produz-se um análogo do procedimento de apresentação de diálogos e de colóquios nas obras de Claude d'Abbeville e de Yves d'Evreux, tanto em francês quanto em tupi, pois essa tradução significa: “a figura de um Tupinambá (ou kiriri) convertível, dotado de palavra para expressar, em sua língua, seu desejo de conversão e de aliança com os franceses (ou com os portugueses)" . No caso dos diálogos de Mamiani, o acordo se dá entre o índio catecúmeno e o padre catequista, sendo a cena de enunciação das verdades da fé a superação das trevas da língua, que articula o saber da doutrina e a fé em Deus. ${ }^{10}$

Quiçá esse artifício retórico do jesuíta, evidente no texto prologal AO LEYTOR, torne-se ainda mais óbvio naquelas seçóes do catecismo em que, por meio de diálogos entre mestre (jesuíta) e discípulo (índio), se encena não apenas um mecanismo de inculcação de

\footnotetext{
7 Pode-se dizer que a redução da língua indígena ao gênero "diálogo" possibilita uma "representação determinada do 'exótico"” (DAHER, Andrea. A oralidade perdida. Rio de Janeiro: Civilização Brasileira, 2012, p. 46), pois que a língua é encenada como ação interlocutória em que ela, pelo procedimento mimético dialogal, ainda rumoreja.

${ }^{8} \mathrm{O}$ escrito de Mamiani e o entendimento de sua pragmática tradutora nos fez chegar a um resultado diferente daquele obtido por Andrea Daher por meio da leitura do Catecismo da lingoa brasilica de Antônio de Araújo, pois diz ela: "Iluminado pelo Espírito Santo, o missionário era o único apto a fazer transitar o sentido - igualmente único, o da Palavra - de língua em língua, como escreve Antônio de Araújo no Prólogo do Catecismo da lingoa brasílica" (DAHER, Andrea. A oralidade perdida. Rio de Janeiro: Civilização Brasileira, 2012, p. 45). Como se vê dos excertos de Mamiani, se o padre é dirigente da atividade tradutora, não é o único competente, a levá-la a termo nem, quiçá, o mais competente, o que parece indiciar a dependência de Mamiani frente aos línguas índios.

${ }^{9}$ Ibidem, p. 23.

${ }^{10}$ Alcir Pécora, em "Vieira, o índio e o Corpo Místico", ao falar da relação entre obscuridade da língua e falta de fé e de saber doutrinal nos escritos vieirianos, assevera o que segue, com o que concordamos: "O topos da 'escuridade' da língua dos indígenas, presente em tantos textos de cronistas e missionários, Nóbrega, Soares de Sousa, Gândavo etc., retomado em vários sermôes e cartas de Vieira, remete tanto à ideia de que se trata de línguas desconhecidas como à de que são desordenadas e sem articulação, em que estão ausentes a luz da razão e a da Graça. O que é dito a respeito das trevas da língua é semelhante ao que se diz do estado da alma dos índios, a que ainda falta o saber da doutrina e a fé de Deus" (PÉCORA, Alcir. Vieira, o índio e o corpo místico. In: NOVAES, Adauto (Org.). Tempo e história. São Paulo: Companhia das Letras, 2006, p. 423-461 [p. 449].
} 
doutrina, mas principalmente o "aprendido" pela evidência das respostas que atendem com perfeição doutrinal às perguntas apresentadas. No DIALOGO I, "Do sinal da Santa Cruz", a encenação de duas vozes evidencia a perfeita consonância entre elas, pois a cada questão apresentada pelo mestre, o discípulo responde prontamente e sempre sem equívocos. Essa cena perfeitamente construída pelo discurso, em que despontam os caracteres modelares dos diálogos a serem empreendidos posteriormente entre jesuítas e índios, visava a, sem sombra de dúvida, produzir emulação. Mas quem deveria emular a quem? Ao ler-se com detenção o diálogo de Mamiani, podemos compreender que a emulaçáo por ele esperada entre seus leitores se funda na expectativa de que a prática catequética espelhe a cena e o texto dialogais, mas seria verossímil esperar que os catecúmenos se vissem no texto e reconhecessem sua própria voz na voz do discípulo, voz essa que, Mamiani afirma, alguns dos índios haviam ajudado a forjar quando da tradução? Esse espelhamento, retoricamente constituído, produzia a performance de forma projetiva: por saber que toda catequese implica atos de fala e enfrentamento entre catequista e catecúmeno, Mamiani compóe diálogos, em que empresta voz a suas personagens, subsumindo padres e índios e situaçóes dialógicas atuais em seu modelo de comunhão dialógica, efetuando a esperança nos futuros catequistas ainda radicados em solo europeu e a crença na fácil convertibilidade dos nativos. Se os padres, para aprender o kiriri e os instrumentos de catequizaçáo, respaldavam-se na simulação de uma prática em que se enfrentavam um futuro catequista - o padre que, na Europa, projetava-se na voz dialogal que lhe caberia no futuro - , e um catecúmeno, que respondia docilmente a tudo o que lhe perguntavam e cuja voz deveria matizar-se ora de inflexóes portuguesas, ora espanholas, ora italianas etc., é preciso perguntar-se como os índios "liam" sua fala no diálogo em que eram encenados. Cabe apresentar aqui um problema histórico, que só pode ser respondido por meio de uma operação de análise histórico-filológica. Poderíamos dizer, pensando na crescente importância da escritura nos séculos XVI e XVII, que tanto mais desejável era a aderência da fala índia ao seu modelo dialogal, pois a própria aderência à letra da escritura evidenciaria a crescente domesticação do índio e a inscrição em sua alma da letra da doutrina. Mas, se nos lembrarmos que a letra inamovível não era norma sequer para a poesia em seus vários gêneros constitutivos, ${ }^{11}$ nem mesmo para os escritos parenéticos, ${ }^{12}$ em línguas ibéricas dos séculos XVI e XVII, como se pode esperar, de forma verossímil, que ela o fosse para catecismos destinados aos índios, cuja pragmática era essencialmente oral? O que inscreve a doutrina na alma indígena é uma palavra em que reverbera um fiat que se faz de forma paulatina, sempre dependente de uma repetição da doutrina em voz alta, em

\footnotetext{
${ }^{11}$ Ver, dentre outras, as seguintes referências: HANSEN, João Adolfo. Pedra e cal. freiráticos na sátira luso-brasileira. In: Revista USP, São Paulo, v. 57, p. 68-85, março/abril 2003; MOREIRA, Marcello. Ut pictura poesis: análise bibliográfico-textual de dois membros da tradição de Gregório de Matos e Guerra. In: Revista USP, v. 57, p. 86-103, março/abril 2003; MOREIRA, Marcello. Critica textualis in caelum revocata? Uma proposta de edição e estudo da tradição de Gregório de Matos e Guerra. São Paulo: Edusp, 2011.

${ }^{12}$ PÉCORA, Alcir (Org.). Antônio Vieira. Sermóes. São Paulo: Hedra, 2003.
} 
que "conteúdos" são sempre mais importantes do que aquilo que hoje chamaríamos "forma”, mas em que o tom pedestre deve ter sido a norma. Assim, os diálogos catequéticos são estruturas modelares, destinadas à performance por atos de fala que "deformam" o modelo, no sentido de que não o reiteram ipsis litteris; desse modo, o repetir "prontamente e com viveza de memória" não deve significar a replicação do texto, mas seu entendimento e reprodução por meio de acréscimos, subtraçóes, paráfrases e outros procedimentos típicos da oralidade. Essa oralidade dominante deveria ser para nós evidente em trechos de cartas jesuíticas, como aquela citada por Alcir Pécora, que refere justamente a viveza da memória indígena: "Em carta escrita ao provincial do Brasil, Vieira refere a 'memória e inteligência' e a 'brevidade com que aprenderam' os guajajaras, que respondiam com 'prontidão e viveza de memória' e muita 'expedição de língua'”. ${ }^{13}$ Os diálogos constitutivos de catecismos, portanto, são a base para novas atualizaçóes deles por meio do sempre imprevisto rumor da língua:

"Do sinal da Santa Cruz"

Mestre: Qual he o sinal do Christão?

Discipulo: A Santa Cruz.

M. Porque?

D. Porque nella foi crucificado JESU Christo.

M. Como se faz o sinal da S. Cruz?

D. Pelo sinal da Santa Cruz livranos Deos nosso Senhor de nossos inimigos, em nome do Padre, \& do Filho, \& do Espirito Santo. Amen JESU.

M. Porque fazemos o sinal da Santa Cruz?

D. Para confessar a Santissima Trinidade, Padre, Filho, \& Espirito Santo, tres pessoas, \&hum só Deos verdadeiro. ${ }^{14}$

MESTRE: Vdjé ibenheté Christão?

Discipulo: Crusá.

M. Soderó?

D. Nó sipodedóinhá JESU Christo idiomó.

M. Vdjé wó bó sipí crusá?

D. Vró. Nó ibenheté crusá dó nunhé hietsãden ená bó cú-Tupã idzené dzumarãden mó idzé Padzú Inhurã nôdehen Espirito Sãto nodehen. Amen JESU.

M. Bóisodé sipí crusá cuná?

D. Bó netçó wonhé Santissima Trinidade dó Padzú, do Inhurâ, dó Espirito Santo cuná; wachánidikié Pessoa cohóbæ, bihé Tupã nerú. ${ }^{15}$

\footnotetext{
${ }^{13}$ PÉCORA, Alcir. Vieira e a condução do índio ao corpo místico do Império Português (Maranhão, 16521661). In: COSTIGAN, Lúcia Helena (Org.). Diálogos da conversão. São Paulo: Edusp, 2005, p. 83-98 [p. 87 ]. ${ }^{14}$ MAMIANI, Luís Vincêncio. Catecismo da doutrina cristã na língua brasilica da Nação Kiriri, op. cit., p. 27-28.

${ }^{15}$ Ibidem, p. 28-29.
} 
A encenação de jesuíta e índio no diálogo produz uma incrível enargeia ${ }^{16}$ percebida pelo leitor do Catecismo como efeito de "presença" da ação apostólica e catequética, em que, para além dos caracteres encenados e de suas correspondentes sententiae, havia a encenação, dentro da cena discursiva criada pelo diálogo, da actio dos caracteres, que, ao falarem, complementam suas palavras com os gestos convenientes à palavra e à situação de sua enunciação, o que criava a precisão de, ao instruir-se sobre o significado da Santa Cruz e ao modo de fazê-la por gestos, gesticular para imitar os que se persignam nas situaçóes que demandam o persignar-se. O índio dos diálogos age em conformidade com as palavras, pois os gestos são condição da verossimilhança da representação, do incremento de sua fides, e, em última instância, da evidência da conversão que é operada pelo procedimento catequético. Desse modo, o índio doutrinado que responde corretamente às questôes que o jesuíta lhe apresenta também sabe acompanhá-las de gestos complementares, táo importantes para o pleno entendimento da doutrina quanto as palavras, pois que são evidência de seu entendimento e de sua aderência a ela. Desse modo, pode-se dizer que o diálogo, enquanto gênero discursivo, apresenta uma função mimética, "figurando assuntos do referencial do lugar segundo preceitos técnicos" que lhe são próprios, e, ao mesmo tempo, outra judicativa, "especificando, nos estilos que dão forma à enunciação, temas e destinatários, as posiçôes interpretativas que permitem receber e avaliar adequadamente as representaçôes" ${ }^{17}$ Nos diálogos catequéticos de Mamiani, estão ausentes os elementos próprios da diatribe, pois neles não há possibilidades polêmico-dogmáticas, como aquelas encenadas no Diálogo da conversão do gentio, de Manuel da Nóbrega. Se, como diz Alcir Pécora relativamente ao citado Diálogo de Nóbrega, a "eficiência persuasiva particular do diálogo" depende de ele "constituir-se discursivamente como uma dramatização da vitória argumentativa sobre o oponente, obtida no interior de um dispositivo que encerra ou prescreve etapas sucessivas de combate intelectual", ${ }^{18}$ nos escritos de Mamiani, por outro lado, o índio dócil, que responde com correção às perguntas doutrinárias, já supõe a superação das "etapas sucessivas do combate espiritual" e propóe a efetuaçáo do locus derivado de Nóbrega do índio como página em branco, em que se inscreve com facilidade o ditado dos padres, figuração essa mais fundada na esperança do que atendida por uma prática catequética que, desde o século XVI, tropeçou em inúmeros percalços.

Pode-se supor também que, porque a escrita de diálogos implicava a modelização da língua kiriri, os diálogos de Mamiani, simplesmente por serem diálogos e não outro gênero de discurso, eram elocutivamente pedestres, tal como se compreendia esse grau de elocução nas retóricas ibéricas dos séculos XVI e XVII, o que reforçava a miragem da voz índia nesses

${ }^{16}$ Ver HANSEN, João Adolfo. Anchieta: poesia tupi e produção da alma. In: ABDALA JR., Benjamin; CARA, Salete de Almeida (Org.). Moderno de nascença: figuraçóes críticas do Brasil. São Paulo: Boitempo, 2006a, p. 11-26; e HEFFERNAN, James A. W. Museum of words. The poetics of ekphrasis from Homer to Ashbery. Chicago: The University of Chicago Press, 2004.

${ }^{17}$ HANSEN, Joáo Adolfo. Pedra e cal. freiráticos na sátira luso-brasileira, op. cit., p. 70.

${ }^{18}$ PÉCORA, Alcir. A conversão pela política. In: Máquina de gêneros. São Paulo: Edusp, 2001, p. 91-115 [p. 97 ]. 
diálogos, pronunciada sem artifícios como o deveria ser a voz selvagem em geral. Pode-se hipotetizar aqui que, diferentemente de poemas, também eles presentes no Catecismo de Mamiani ("Em louvor da Virgem Santissima Mãy de Deos", "Do nome Santissimo de IESUS") - em que se dá, pela metrificação, a imposição de uma respiração europeia que acultura a língua indígena, ao submetê-la "a um sistema musical de equivalências relacionadas ao princípio da similitude e, portanto, ao princípio metafísico de identidade, Deus"19 —, os diálogos, ao encenarem o índio catecúmeno como conhecedor da doutrina cristã, cujos princípios fundamentais ele enuncia na forma de respostas ao catequista, fazem-no pela imitação de uma fala aparentemente isenta de toda arte, pois seu artifício é o de justamente aparentar a falta de sua aplicação, pois os padres, que compóem os textos portugueses e que tomam parte e dirigem a tradução para o kiriri, se incumbem, por sua própria aderência à consuetudo dos vários gêneros praticados, que supóe um decoro adequado a cada um deles, de aplicar nos textos kiriris o mesmo artifício aplicado ao seu análogo português. Desse modo, graus elocutivos são pensados pelos padres como necessários à produção do decoro próprio dos vários gêneros praticados em línguas indígenas, como afirma o jesuíta Diego González Holguín (1560-1620) em sua gramática do quéchua. Ele assevera, em sua gramática, que não a compôs para facilitar a confissão, pois já havia obra impressa no Reino do Peru destinada a esse fim, remetendo, portanto, aos impressos de Antonio Ricardo (1584), de que consta um confessionário. Segundo ele, uma gramática faz-se precisa porque sem ela não se pode cultivar a língua a ponto de se poder falar ou, sobretudo, pregar com correção, cópia de palavras e elegância no emprego de ornatos. ${ }^{20} \mathrm{~A}$ gramaticalização é etapa prévia para que se produza uma oratória sacra em língua quéchua, pois as estruturas elocutivas que ornam o discurso dependem de uma norma de que constituem variaçóes estilísticas, ou seja, antes da retórica, a gramática. É, inclusive, por essa razão, a de formar pregadores, que Diego González Holguín divide sua gramática em quatro livros, os dois primeiros destinados a ensinar a gramática propriamente dita ("haciendo el arte de los dos primeros, y reduciendo á ellos todo lo necesario para saber bien la Lengua y todo lo que pertenece á gramática”), e os terceiro e quarto votados ao ensino da composição de discursos oratórios sacros, ocupando-se o terceiro da copia verborum ("por eso reduje al tercero libro los modos de hallar gran copia de vocablos, así de nombres, verbos, participios, como adverbios") e o quarto ("y al cuarto libro, lo que toca á la elegancia; enseñando á componer, así oraciones, como todas partes de la oracion, con las particulas de ornato"), do ornamento. ${ }^{21}$ Como a ação dos padres da Companhia de Jesus apresenta forte unidade em todos os lugares em que obraram, é de supor que aquilo que afirma Holguín seja válido também para Mamiani, mesmo que os textos em kiriri sejam em reduzido número.

\footnotetext{
${ }^{19}$ HANSEN, João Adolfo. A escrita da conversão, op. cit., p. 33.

${ }^{20}$ Ver HOLGUíN, Diego Gonzales. Gramática y arte nueva de la lengua general de todo el Peru, llamada Qquichua, o lengua del Inca. Nueva edición revista y corrigida, 1842.

${ }^{21}$ Ibidem, p. XI-XIV.
} 
Se se pode concordar com Andrea Daher quando assevera que "Se em relatos franceses o Tupinambá fala, o 'índio do jesuíta', por sua vez, não é dotado de palavra"22 — porque nos textos jesuíticos não há discursos diretos em que haja índios a falar —, é preciso pensar como o diálogo catequético, gênero por necessidade mimético, para além de sua cena dialógica ideal, indiciava um falar, impossível de ouvir nos dias de hoje, mas, por isso mesmo, necessitado de ser hipotetizado por uma operação filológica que vise a uma melhor compreensão do diálogo enquanto gênero letrado, mas destinado sempre a uma pragmática. A simplicidade elocutiva dos diálogos catequéticos mimetiza o tom pedestre da fala dialogada e finge ao mesmo tempo o índio como infans, aquele que aprende a falar, pois de fato o que fala nos diálogos é algo novíssimo para ele.

Sforza Pallavicino, ao citar uma crítica de Pico della Mirandola aos escritores sacros que sobrecarregavam suas composiçóes de ornatos, afirmava que estes diminuem o grau de credibilidade do discurso, pois nas coisas santas a eficácia persuasiva deve derivar das razóes, mas não dos artifícios, ${ }^{23}$ ou seja, para a verdade revelada, justamente por ser verdade, é requerida uma maneira semplice e piana de exposição: ${ }^{24}$

Le ragioni del Pico si riducono alle seguenti: che se tratassi dell'eloquenza, gli ornamenti di lei tolgon la fede alla verità, e la rendono incerta; mentre il lettore dubita se la forza che sente farsi all'intelletto, deriui dall'efficacia della ragione, ò dall'artificio dello Scrittore: Perciò nelle Sacre Lettere haver Dio voluto vno símplice stile e piano, col quales'è convertito el mondo. (PALLAVICINO, 1662, p. 24)

Quando Mamiani afirma que seu Catecismo foi traduzido por ele e pelos demais línguas da Companhia, mas com o auxílio imprescindível dos próprios índios, que foram responsáveis, em última instância, com os mestres línguas da Companhia, pela verificação das correspondências entre texto português e texto kiriri, ele, como já o dissemos, atribui ao seu livro, sobretudo a suas partes dialogais, uma dimensão oral evidente, em que rumoreja ainda

\footnotetext{
${ }^{22}$ DAHER, Andrea. A oralidade perdida, op. cit., p. 27.

${ }^{23}$ Há uma outra importante passagem no tratado de Sforza Pallavicino, em que se produz uma contundente crítica do excesso elocutivo, com ênfase no emprego de metáforas arditte: "Poichè il dire, che la verità è tanto bella per sè medesima, che ogni straneo liscio le imbratta e non le adorna le guancie; che alla sua onestà disdicono tutti i belletti; e mille simiglianti dettati; è vn voler appunto imbellettar con metafore la bugia perche apparisca verità à gl'ingegni di poca vista" (PALLAVICINO, Sforza. Considerazioni sopra arte dello stile, e del dialogo. Roma: Eredi del Corbelleti, 1646, p. 36).

${ }^{24}$ Alcir Pécora, ao estudar o Diálogo da Conversáo do Gentio, de Nóbrega, cita preceito de Demétrio em que se distingue a fala coloquial (sermo) da formal (contentio), sendo a primeira própria do gênero dialogal (PÉCORA, Alcir. A conversão pela política, op. cit., p. 97), preceito esse que é reciclado por Pallavicino como vimos acima. Contudo, como afirma Alcir Pécora, entre os letrados dos séculos XVI e XVII, "o diálogo é sobretudo discurso que evidencia uma prática civil, cortês e espiritualmente refinada, sem ser professoral ou especializada, cujo modelo histórico máximo certamente se formula n'O Livro do Cortesão, de Castiglione" (Ibidem, p. 97-98), o que diferencia a proposta desse tipo de diálogo daqueles de Mamiani.
} 
a língua dos índios línguas; essa evidência de oralidade se encontra ainda em outra seçóes de $A O L E Y T O R$, em passagem, por exemplo, em que Mamiani declara seu aprendizado da língua kiriri de "oitiva", o que torna óbvia a dimensão oral de seu conhecimento dessa língua ainda não gramaticada ao tempo da confecção do Catecismo, mesmo que no juízo do autor já estivesse reduzida, é claro, de certa forma em arte: "Alèm da experiencia de doze anos de lingua entre os Indios, nos quaes desde o primeiro anno atè o presente fui de proposito notando, reparando, \& perguntando não sómente para entender, $\&$ falar doutiva [...]". ${ }^{25}$

Ao dizer que aprende o kiriri de oitiva, em diálogo com os silvícolas, ou então ouvindo diálogos travados entre índios, em que constantemente se intromete em busca de informaçôes mais precisas sobre o sentido de vocábulos, sobre os usos linguísticos respeitantes ao que hoje chamamos sintaxe, Mamiani faz-nos compreender que a palavra inscrita em seu texto é o resíduo de uma vida rumorejante, a que cada ação catequética insufla por mais uma vez um novo pneuma. Mas, é preciso estar atento para o procedimento adotado pelos padres para a promoçâo da catequese de silvícolas no Novo Mundo. O padre, caso deseje verificar o aprendizado pelo catecúmeno das verdades da fé cristá presentes nos diálogos, deve saber a língua peregrina falada por este, pois desse saber depende a verificação de estar o índio pronunciando as palavras corretas para que não ocorra nenhum desvio doutrinal que passe despercebido pelo catequista. Desse modo, o maior conhecimento da língua indígena, evidente na maior capacidade de correta prolaçấo das palavras, faz com que o catequista fale de doutrina cristâ, mas com a condição de que a fale pela imposição aos seus órgãos fonadores e ao seu corpo de uma língua que não é a sua, mas que barbaramente rumoreja em sua boca, mas já não tão bárbara porque abrandada pela verdade da fé revelada que ela já é capaz de enunciar; esse procedimento de aprendizado pela escuta e pelo seu necessário complemento, que é a replicação do ouvido, é o que se evidencia em um sermão de Antônio Vieira, citado por Alcir Pécora:

Por vezes me aconteceu estar com o ouvido aplicado à boca do bárbaro, e ainda do intérprete, sem poder distinguir as sílabas, nem perceber as vogais ou consoantes de que se formavam, equivocando-se a mesma letra com duas ou três semelhantes, ou compondo-se — o que é mais certo — com mistura de todas elas: umas tão delgadas e sutis, outras tão duras e escabrosas, outras táo interiores e escuras, e mais afogadas na garganta que pronunciadas na língua; outras tâo curtas e subidas, outra táo estendidas e multiplicadas, que não percebem os ouvidos mais que a confusão, sendo certo, em todo o rigor, que as tais línguas não se ouvem, pois se não ouve delas mais que o sonido, e não palavras desarticuladas e humanas. ${ }^{26}$

\footnotetext{
${ }^{25}$ MAMIANI, Luís Vincêncio. Catecismo da doutrina cristã na língua brasílica da Nação Kiriri, op. cit., Ao Leytor, p. 3.

${ }^{26}$ Apud PÉCORA, Alcir. Vieira, o índio e o corpo místico. In: NOVAES, Adauto (Org.). Tempo e história. São Paulo: Companhia das Letras, 2006, p. 423-461 [P. 450].
} 
Se nos lembrarmos agora de que esses diálogos catequéticos, mesmo que fundados em um modelo de natureza formular, eram, no entanto, performados, com tudo aquilo que a performance implica em termos de alteraçôes da matriz textual que deveria supostamente replicar, ${ }^{27}$ não é possível pensá-los fora de um regime pragmático de forte oralidade, que o estilo dialogal prescrito para sua composição apenas auxiliava a imitar em suas variantes escriturais.

Não há como discordar, por outro lado, do que afirma Michel de Certeau, quando diz que a escrita "combina o poder de reter o passado (enquanto que a 'fábula' selvagem esquece e perde a origem) e o de superar indefinidamente a distância (enquanto que a 'voz' selvagem está limitada ao círculo evanescente de seu auditório)"; $; 8$ mas, se a escrita supera a evanescência da pura fala e, também, aquela de seu auditório, por outro lado estabiliza a voz índia nem que seja para fazê-la falar da história de sua salvação pelo resgate nela operado pela ação catequética, que, ao mesmo tempo, permite pela encenação da voz índia que vence distâncias e que se póe em presença de sempre novos auditórios na Europa a expansão da crença na proximidade da realizaçấo do paráclito, quando Babel será finalmente superada. ${ }^{29} \mathrm{~A}$ operaçáo de traduçáo jesuítica, como o diz Joáo Adolfo Hansen, age pela concessão aos termos peregrinos de um suplemento de alma católico, como ao termo tupi "Tupá”, por exemplo, operaçáo essa em que o padre "produz a alma selvagem enquanto lhe fornece a memória católica do Bem em sua própria língua”. ${ }^{30}$

A dimensão da oralidade dos diálogos torna-se manifesta na larga seção de "Advertencias sobre a pronunciaçaô na língua Kiriri”, em que Mamiani, após falar da barbaridade do kiriri, de seus sons quase impossíveis de pronunciar pelo estrangeiro, consegue, no entanto, reduzi-los a grafemas usados na Europa ou por ele inventados para a sua inscrição — sons esses de tão difícil prolação que os próprios línguas da Companhia estâo em perpétua dúvida quanto ao melhor modo de escrevê-los e de pronunciar muitos dos vocábulos dessa língua (retomando, portanto, uma tópica que, como vimos, já se fizera presente em Antônio Vieira):

\footnotetext{
${ }^{27}$ Ver ZUMTHOR, Paul. Essai de poétique médiévale. Paris: Édtions du Seuil, 1972; ZUMTHOR, Paul. A letra e a voz: a "literatura" medieval. Sâo Paulo Companhia das Letras, 1993; CERQUIGLINI, Bernard. Éloge de la variante: histoire critique de la philologie. Paris: Éditions du Seuil, 1989.

${ }^{28}$ CERTEAU, Michel de. Etnografia. A oralidade ou o espaço do outro: Léry. In: CERTEAU, Michel de. $A$ escrita da história. Rio de Janeiro: Forense Universitária, 2002, p. 211-242 [p. 217].

${ }^{29}$ Eduardo Subirats, ao discorrer sobre a lógica da colonizaçáo, o faz por um viés que articula a conquista imperial ibérica e a ação catequética à "consciência de culpa europeia", para além de referir a ação missionária como "fanático espírito de missão e conversão" (SUBIRATS, Eduardo. A lógica da colonização. In: NOVAES, Adauto (Org.). Tempo e história. São Paulo: Companhia das Letras, 2006, p. 399-410 [p. 399 ]), que se nos afigura anacrônica nos termos por ele propostos. Alcir Pécora, em pertinentíssima crítica a Alfredo Bosi, já dissera que chaves interpretativas que propõe, por exemplo, um jesuíta como Antônio Vieira ora "católico liberal", ora "marxista", só fazem sentido à luz de critérios próprios da recepção, mas não de uma leitura que conceba o objeto segundo critérios de produção que lhe são coetâneos (Ver PÉCORA, Alcir. Vieira, o índio e o corpo místico, op. cit., p. 459). Para uma oposição à interpretação "revisionista" da colonização americana proposta por Subirats, ver o texto de Alcir Pécora a que esta nota faz remissão.

${ }^{30}$ HANSEN, João Adolfo. Anchieta: poesia tupi e produção da alma, op. cit., p. 17.
} 
Chamei difficultoso assumpto, porque he tam embaraçada esta lingua assim na pronunciação, como nas suas frazes, que os mesmos nossos Religiosos bons linguas, nunca concordárão no modo, com que se houvessem de escrever, $\&$ pronunciar muitos vocabulos. ${ }^{31}$

A seção "Advertencias sobre a pronunciaçaó na língua Kiriri”, em que se ensina aos futuros missionários e curiosos em geral como se devem pronunciar os vocábulos e frases kiriris, permite aos europeus fazer soar, mesmo que a distância e de modo imperfeito, essa língua em que já "oram" índios. Se pensarmos nessa audição dominante, tanto para os índios que ouviam a si próprios ao responder às questôes constituintes dos diálogos do Catecismo quanto para os aprendizes europeus de línguas peregrinas, fica patente que o caráter artificioso dos diálogos é justamente o de imitar por seu tom pedestre, simples, plano, uma fala selvagem em sua pureza, não ornada por necessidade e, por isso mesmo, por ser aparentemente nada artificiosa, mais verdadeira, enunciadora no seu estilo chão das verdades da religião católica a que ela adere a cada resposta dada a perguntas do Catecismo.

Pode-se dizer que a perícia retórica de Mamiani se evidencia justamente nessa capacidade de síntese entre uma oralidade índia, em que se faz soar o gentio para que ele possa se reconhecer nesses sons que ele próprio articulará à semelhança do silvícola católico que ele deve emular, seu espelho perfeito encenado nos diálogos do Catecismo, e o estilo pedestre do gênero "diálogo", por ele escolhido para a encenação dos caracteres que aparentam uma interlocução que sabemos ser de mão única, no diálogo escrito, mas provavelmente pouco passiva nas suas múltiplas performances pragmáticas. Desse modo, pode-se asseverar aqui que os procedimentos de aculturação a que o índio estava sujeito por meio da gramaticalização de sua língua e dos usos textuais a que ela se prestava nas mãos de padres jesuítas, dentre outros agentes missionários, eram bastante variados e englobavam desde a composição de poemas à escrita de diálogos, em que os dispositivos de exercício do poder são complementares, mas distintos.

Por fim, há ainda outra observação a fazer sobre a remanescente oralidade índia. Ao auxiliar os padres a inscrever sua voz nos diálogos, ao tornar índia, pela tradução kiriri, a doutrina cristã, que, logo depois, se inscreverá pela repetição deformada do modelo nos corpos dos catecúmenos, os índios se tornam cocriadores de instrumentos de exercício de poder, que encenam, pela escritura, sua domesticação ao metaforizá-la pelo emudecimento crescente de uma oralidade domesticada pela ação escritural. Se soa, e ainda o faz nos diálogos catequéticos, só o faz para dizer o que o outro quer, podendo-se entender como emudecimento "a incapacidade de dizer o que se quer dizer fora de toda coerção colonizadora". Pode-se afirmar, portanto, que a inscrição é o modo por excelência de domesticação, em que a língua índia se desembaraça pelo fiar do texto catequético, que lhe dá arte, como escritura,

\footnotetext{
${ }^{31}$ MAMIANI, Luís Vincêncio. Catecismo da doutrina cristã na língua brasílica da Nação Kiriri, op. cit.. Ao Leytor, p. 2.
} 
e verdade, como doutrina. Desse modo, pode-se dizer que toda fala é uma fala autorizada, e, por conseguinte, que a oralidade não é completamente recalcada, pois que se a permite sob condição de se falar dentro de determinadas balizas do dizer. Mas, por outro lado, para além de todo texto e de toda escritura, há a performance, que é incapaz de perfeita reiteração, que inflete, que replica por acréscimo e subtração, por perífrase, por paráfrase, em que muito do dito já não há, e em que muito do que se não disse, há.

A voz índia, como toda voz, deve ter tido uma espessura difícil de domesticar, que os escritos de Mamiani procuram captar em sua forma ideal, justamente porque a escritura permite representar todo índio como um tipo, jesuíta e padre como ethe, e, desse modo, produzir tipos universais com que a ação apostólica sonha, uma miragem quase inalcançável. ${ }^{32}$

\section{(II) Coda}

Não pode haver equívoco quanto ao caráter performático de toda catequização caso pensemos nos modos por que o diálogo catequético modelar, aquele presente em catecismos bilíngues, passa do regime escriturário, que fixa a lição (de lectio, derivada de lego — ler —, etimologicamente, "o que se lê"), para o domínio da voz, em que estáo implicados simultaneamente no ato de comunicação um tempo, o presente, e condiçôes variáveis de expressão e de percepção. Em toda prática catequética, há pelo menos dois participantes implicados no ato de maneira imediata, catequista e catecúmeno, e embora se possa pensar que cabe ao primeiro dirigir o segundo, direção essa que se resumiria a fazer o outro fiar seu discurso pelo fio da escritura, esse modo de assim conceber a catequização se funda na crença de um primado da escritura, que o catecúmeno inscreveria em si por repetição, vencido pela redundância. Paul Zumthor, em um de seus livros, fala-nos da diferença que há entre recepção e performance, e, quanto à primeira, assevera ser ela "um termo de compreensão histórica, que designa um processo, implicando, pois, a consideração de uma duração". ${ }^{33}$ Desse modo, a recepçáo se identifica "com a existência real de um texto no corpo da comunidade de leitores e ouvintes. Ela mede a extensão corporal, espacial e social onde o texto é conhecido e em que produziu efeitos: 'a recepção de Shakespeare na França, no século XVIII'” ${ }^{44}$ Se é verossímil

\footnotetext{
${ }^{32}$ Franck Lestringant, em um de seus belos ensaios sobre o mundo americano, afirma que, quando da descoberta do Novo Mundo, "a consumação de um espaço enfim encerrado em si mesmo implicava a perfeição da duração histórica" (LESTRINGANT, Frank. O conquistador e o fim dos tempos. In: NOVAES, Adauto (Org.). Tempo e história. São Paulo: Companhia das Letras, 2006, p. 411-422 [p. 412]), de que deriva ser o índio "desapossado de seu presente para ver-se lançado no tempo mítico das origens que não são de modo algum as suas", e, desse modo, "o índio é simultaneamente impelido na direção de um desfecho apocalíptico, uma segunda vez expulso da História, na perspectiva de uma destruição ou de uma redenção igualmente inelutáveis" (Ibidem, p. 411).

${ }^{33}$ ZUMTHOR, Paul. Performance, recepção, leitura. Sáo Paulo: Cosac Naify, 2014, p. 51.

${ }^{34}$ LESTRINGANT, Frank. À espera do outro. Nota sobre a antropofagia da Renascença: um desafio ao
} 
historicamente afirmar que os diálogos catequéticos se destinavam, em primeiro lugar, aos próprios missionários, que tinham de aprender línguas bárbaras do Novo Mundo e os instrumentos discursivos empregados na evangelização, de que deriva haver uma "recepção" de gramáticas de línguas índias e de diálogos não apenas entre missionários nas Américas, mas, sobretudo, entre os que esperavam na Europa o tempo de sua missionação, gramáticas e diálogos, enquanto discursos "modelares", implicavam mais de uma forma de modelização. Se as gramáticas modelizavam a língua indígena a ser aprendida pelos padres, os diálogos catequéticos operavam por sua estrutura mimética uma homologia entre escritura, na medida em que o diálogo manuscrito ou impresso era fruto de uma operaçáo escriturária, e performance, ao fazer crer, previamente a toda prática catequética, que a relação dialógica entre catequista e catecúmeno perfeita seria apenas a replicação da cena dialógica fruto da inscrição. É como se o diálogo a ser travado fosse balizado anteriormente a todo enfrentamento por uma gramaticalização - a da língua índia normalizada, e, por isso mesmo, passível de tradução - , uma retoricização e sua complementar poetização. A performance, embora participe da recepção como um seu momento, e, nesse sentido, esteja integrada na duração, não se confunde com ela, como a recepção, pois o que a caracteriza não é a história, mas a evanescência, que dificilmente deixa vestígios. Ao propormos uma interpretaçáo para os diálogos catequéticos que circularam no mundo americano entre os séculos XVI e XVIII, integrando-nos à recepção descontínua desses discursos, fazemo-lo, paradoxalmente, para compreender o momento de sua recepção que equivaleria ao da performance, assumindo que nossa operaçâo leitora quer ir além do texto que se dá a ler. Pode-se dizer que a crença na eficácia da operação escriturária, que multiplica pelo prelo e pela manuscritura catecismos no mundo americano, destinados a uma nova inscrição nos próprios nativos, respalda-se em um a priori destituído de toda pertinência, pois o catecismo, enquanto discurso, mais, enquanto gênero discursivo, implica, como todo gênero discursivo, "um acordo entre a oferta e a demanda, texto e leitura, acordo que provoca o surgimento de um sentido apropriável pelo leitor", em suma, um horizonte de expectativa, como o denominava Hans Robert Jauss, ${ }^{35}$ que sequer pode ser concebido quando do embate entre catequista e catecúmeno. Nesse sentido, é preciso reconhecer pela reflexão crítica uma forte tensão entre o "gramaticalmente" da escritura e o "verbalmente" da performance, relacionados, o primeiro, ao catequista e ao seu apego à palavra, palavra esta de ordem, pois portadora do sacrum, e, o segundo, ao catecúmeno, estátua de murta, como o chamava Antônio Vieira, ${ }^{36}$ cuja voz, como em tudo o mais, sempre deve ter excedido a expectativa dos religiosos, ou, às vezes, ficado aquém dela. O que podemos verossimilmente supor, no entanto, é que, quanto ao

espírito de sistema. In: NOVAES, Adauto (Org.). A outra margem do Ocidente. São Paulo: Companhia das Letras, 1999, p. 33-51 [p. 51].

${ }^{35}$ Ver JAUSS, Hans Robert. A história da literatura como provocação à teoria literária. Trad. Sérgio Tellaroli. São Paulo: Ática, 1994.

${ }^{36}$ Ver Sermão do Espírito Santo. 
catequista, este se vê enredado por duas formas de "produçâo" do discurso catequético, uma ligada à escritura, que lhe chega pronta quando o próprio catequista não é o responsável pela composição do catecismo de que se vale para a instrução dos nativos, e, outra, própria da oralidade. Neste segundo tipo de "produçáo", embora o padre possa simplesmente balizar sua actio pela replicação da palavração do texto escrito, o índio, a quem importa fazer replicar a escritura e sua substância, por nada conhecer do regime escriturário, por nada saber do catecismo e de sua natureza genérico-retórico-político e teológica, da palavra revelada, do sacrum tremendo de que ela é portadora etc., deveria sempre claudicar quando, na "cena" em que se conjugam por necessidade "recepção" da escritura e "reprodução" dela pela voz, esta deveria infletir aquela de vária maneira, chegando-se a resultados próximos àqueles derivados da prática poética caracterizada pela movência ${ }^{37}$ (ZUMTHOR, 1972). Essa "produção" de discurso em situação de oralidade pura, própria do polo catecúmeno, implicaria, também, uma "conservação" característica de situaçóes de oralidade pura, baseada na memória. Implicaria, pois, pela "reiteração" imperfeita, como o é em geral aquela própria de regimes de oralidade pura, "incessantes variaçôes re-criadoras", que tornam o sagrado disfórico por disfonia ou distúrbios e intervençôes próprios do âmbito da voz. É preciso dizer ainda que, por mais que os padres da Companhia de Jesus e os religiosos da catolicidade europeia estivessem ligados a uma economia escriturária, de que derivaria uma relativa surdez frente aos valores da voz, era preciso no mundo americano recuperar a acuidade da audição, e se pode dizer que a perspicuidade - categoria retórica que associamos em demasia ao texto e à escritura - dizia respeito, nos empreendimentos missionários do Estado do Brasil, sobretudo à voz, a que se produzia e a que se ouvia por parte tanto de missionários quanto de nativos. Cumpre recuperar, mesmo que hipoteticamente, aquele elemento que os catecismos, sejam impressos ou manuscritos, acabam por elidir, mas que é central na prática catequética: a enunciação. $\mathrm{O}$ catecismo, por sua evidente estrutura dialógica, se esforça por criar a miragem de uma cena e a atualidade da enunciaçáo, e seu leitor, ora ocupando a posição do que enuncia, ora a do que ouve, ilude-se quanto à dissimetria de duas situaçóes muito distintas de percepçâo (performance versus leitura): na leitura do catecismo, "a escrita só pode sugerir a enunciação, a partir de marcas dêiticas, frágeis e frequentemente ambíguas, senão artificialmente apagadas". ${ }^{38}$ Há uma outra defasagem entre a performance que envolve catequista e catecúmeno e a leitura do catecismo feita por um leitor solitário: no que respeita à primeira, um elemento dela é por necessidade a signatura, resultado da atividade do olho humano "que transforma em signum o que ele vê"; 39 mas o que catequista e catecúmeno veem em comum? Mais, como podem ver algo em comum, se os códigos gestuais diferem, assim como as línguas que falam? E mesmo que o catequista aprenda a língua do catecúme-

\footnotetext{
${ }^{37}$ Ver ZUMTHOR, Paul. Essai de poétique médiévale, op. cit.

${ }^{38}$ Ibidem, p. 71.

${ }^{39}$ Ibidem, p. 71.
} 
no, falando-a como estrangeiro, conseguiria deixar de ser efetivamente forâneo frente à língua aprendida e a seus falantes e tinha algum interesse em deixar de sê-lo? O texto escrito, como o diz Paul Zumthor, "reivindica sua semioticidade", mas náo cremos, como o faz o filólogo suíço, que o "estilo" possa escapulir "daí em parte", pois ele é "grau” da elocução e táo convencional e significante em sua convenção quanto os outros elementos do discurso, e implicava, correlatamente, a adequaçáo entre estilo, pronunciatio e actio, o que tornava a proferição altamente regrada por uma prática cultural. Se assim é, como podia o índio dela apropriar-se para produzir a decodificação de signos analisáveis, ou seja, como poderiam ele e o catequista se reunir pela mediaçáo de uma monstratio que os separava a princípio, pois não é isso que estava implicado no diálogo catequético?

\section{Referências bibliográficas}

ANCHIETA, José de. Diálogo da fé. São Paulo: Loyola, 1988.

. Arte de gramática da língua mais usada na costa do Brasil. Edição fac-similada. Salvador: Universidade Federal da Bahia, 1990.

CERQUIGLINI, Bernard. Éloge de la variante: histoire critique de la philologie. Paris: Éditions du Seuil, 1989.

CERTEAU, Michel de. Heterologies. Discourse on the other. Minneapolis: University of Minnesota Press, 1986.

. Etnografia. A oralidade ou o espaço do outro: Léry. In: CERTEAU, Michel de. A escrita da história. Rio de Janeiro: Forense Universitária, 2002, p. 211-242.

DAHER, Andrea. A oralidade perdida. Rio de Janeiro: Civilização Brasileira, 2012.

Doctrina christiana y catecismo para instrucción de los indios. Ciudad de los Reyes: Antonio Ricardo, 1584.

HANSEN, João Adolfo. Pedra e cal. Freiráticos na sátira luso-brasileira. Revista USP, São Paulo, v. 57, p. 68-85, março/abril 2003.

. A escrita da conversão. In: COSTIGAN, Lúcia Helena (Org.). Diálogos da conversão. São Paulo: Edusp, 2005, p. 15-43.

. Anchieta: poesia tupi e produção da alma. In: ABDALA JR., Benjamin; CARA, Salete de Almeida (Org.). Moderno de nascença: figuraçôes críticas do Brasil. São Paulo: Boitempo, 2006a, p. 11-26.

. Categorias epidíticas da ekphrasis. Revista USP, São Paulo, v. 71, p. 85-105, setembro/novembro 2006. 
- Códigos bibliográficos, escribas, manuscritura e códices da poesia atribuída a Gregório de Matos e Guerra. In: MOREIRA, Marcello. Critica textualis in caelum revocata? Uma proposta de edição e estudo da tradição de Gregório de Matos e Guerra. São Paulo: Edusp, 2011, p. 13-41.

HEFFERNAN, James A. W. Museum of words. The poetics of ekphrasis from Homer to Ashbery. Chicago: The University of Chicago Press, 2004.

HOLGUÍN, Diego Gonzales. Gramática y arte nueva de la lengua general de todo el Peru, llamada Qquichua, o lengua del Inca. Ciudad de los Reyes: Francisco del Canto, 1607. - Gramática y arte nueva de la lengua general de todo el Peru, llamada Qquichua, o lengua del Inca. Nueva edición revista y corrigida, 1842.

JAUSS, Hans Robert. A história da literatura como provocação à teoria literária. Trad. Sérgio Tellaroli. São Paulo: Ática, 1994.

LESTRINGANT, Frank. À espera do outro. Nota sobre a antropofagia da Renascença: um desafio ao espírito de sistema. In: NOVAES, Adauto (Org.). A outra margem do Ocidente. São Paulo: Companhia das Letras, 1999, p. 33-51.

. O conquistador e o fim dos tempos. In: NOVAES, Adauto (Org.). Tempo e história. São Paulo: Companhia das Letras, 2006, p. 411-422.

MAMIANI, Luís Vincêncio. Catecismo da doutrina cristã na língua brasílica da Nação Kiriri. Lisboa: Miguel Deslandes, 1698.

MOREIRA, Marcello. Ut pictura poesis: análise bibliográfico-textual de dois membros da tradição de Gregório de Matos e Guerra. Revista USP, São Paulo, v. 57, p. 86-103, março/ abril 2003.

. Critica textualis in caelum revocata? Uma proposta de ediçäo e estudo da tradiçāo de Gregório de Matos e Guerra. São Paulo: Edusp, 2011.

PALLAVICINO, Sforza. Considerazioni sopra arte dello stile, e del dialogo. Roma: Eredi del Corbelleti, 1646.

PÉCORA, Alcir. A conversão pela política. In: PÉCORA, Alcir. Máquina de gêneros. São Paulo: Edusp, 2001, p. 91-115.

(Org.). Antônio Vieira. Sermões. São Paulo: Hedra, 2003.

. Vieira e a condução do índio ao corpo místico do Império Português (Maranhão, 1652-1661). In: COSTIGAN, Lúcia Helena (Org.). Diálogos da conversão. São Paulo: Edusp, 2005, p. 83-98.

. Vieira, o índio e o corpo místico. In: NOVAES, Adauto (Org.). Tempo e história. São Paulo: Companhia das Letras, 2006, p. 423-461.

SUBIRATS, Eduardo. A lógica da colonização. In: NOVAES, Adauto (Org.). Tempo e história. São Paulo: Companhia das Letras, 2006, p. 399-410. 
VIEIRA, Antônio. Sermôes. Organização de Alcir Pécora. São Paulo: Hedra, v. 1, 2003. . Sermôes. Organização de Alcir Pécora. São Paulo: Hedra, v. 2, 2003.

ZUMTHOR, Paul. Essai de poétique médiévale. Paris: Édtions du Seuil, 1972. . Intertextualité et Mouvance. Littérature, Paris, v. 41, p. 8-16, 1981. . A letra e a voz: a "literatura" medieval. São Paulo: Companhia das Letras, 1993. , Paul. Performance, recepção, leitura. São Paulo: Cosac Naify, 2014. 